811.163.41'367

811.163.41'367.625

https://doi.org/10.18485/sj.2017.22.1.36

НАТАША Р. МИЛИВОЈЕВИЪ ${ }^{*}$

Универзитет у Новом Саду

Филозофски факултет
Оригинални научни рад

Примљен: 11. 06. 2016.

Прихваћен: 15. 12. 2016.

\title{
О СТРУКТУРИ И КЛАСИФИКАЦИЈИ КОНСТРУКЦИЈА ДИРЕКТИВНОГ КРЕТАҢА СА ГЛАГОЛИМА СТВАРАњА ЗВУКА У СРПСКОМ ЈЕЗИКУ
}

Рад представља покушај доследне синтаксичке и семантичке класификације конструкција директивног кретања са глаголима стварања звука у српском језику. Посматране конструкције сврстане су у два синтаксичка и четири семантичка типа на основу низа дефинисаних морфо-синтаксичких и семантичких критеријума, са теоријског аспекта граматике конструкција и према поставкама типолошке класификације природних језика Л. Талмија (Talmy 2000a, 2000b). Основна методологија истраживања је квалитативна анализа реченичног корпуса који садржи примере из књижевних текстова и из електронског корпуса Савременог српског језика. Истраживање показује да, када је реч о просторном кретању, српски језик испољава доминантно понашање језика са сателитским ситуативним оквиром, те да класа сателита у српском језику обухвата глаголске префиксе, предлоге и падежне суфиксе.

Кључне речи: граматика конструкција, српски језик, глаголи стварања звука, директивно кретање, трајекторија, класа С.

"natasa.milivojevic@ff.uns.ac.rs 


\section{1. УВОДНА РАЗМАТРАЮА}

Основни задатак истраживања које ће бити приказано у овом раду јесте да теоријски и емпиријски сагледа и објасни једну према структури аргумената непрототипску конструкцију којом се исказује директивно кретање (енг. directed motion) у српском језику. Реч је о конструкцији која у себи садржи глагол стварања звука (енг. sound emission verb) на позицији управног предиката. Глаголи стварања звука по својој лексичкој спецификацији нису блиски глаголима кретања, односно они својим значењем не спецификују кретање. Интерпретација кретања у овом случају резултат је семантичко-синтаксичке композитивности на нивоу шире морфо-синтаксичке структуре којом управља глагол стварања звука. У оквиру директивне конструкције са значењем кретања, глагол стварања звука најчешће лексикализје начинску компоненту кретања, а то је звук који је или последица кретања, или је на неки други начин повезан са кретањем, као у следећим реченицама:

1.

a) Камиони су протутњали низ друм.

б) Метак је прозвиждао кроз прозор.

У примерима 1а и 1б, интерпретација кретања постиже се путем специфичне структуре аргумената (енг. argument structure). Глагол стварања звука везује предлошко-падежну синтагму којом се експлицитно лексикализује трајекторија кретања: низ друм/кроз прозор. Такође, реч је о префиксалним глаголима, те се спецификација правца кретања у наведеним примерима означава глаголским префиксом про-. Значење „звук уместо кретања” доступно је захваљујући сателитском аргументу управног предиката којим се исказује путања по којој се креће објекат локализације камиони/метак, а којим се путем семантичко-синтаксичке композиције „допуњава” лексичка спецификација глагола стварања звука протутьали/прозвиждао, тако да он у оквиру конструкције означава директивно кретање.

Важан део анализе обухвата морфо-синтаксичке елементе који припадају класи сателита, или класи $C^{1}$ у српском језику, према типолошкој језичкој класификацији Ленарда Талмија (Talmy 1985, 2000a, 2000b). Талми природне језике сврстава у класе на основу њиховог лексичког и морфо-синтаксичког капацитета за кодирање просторног кретања. Српски језик испољава релативно висок степен слободе када је реч о исказивању кретања путем глагола стварања звука и такво значење реализује се низом структурно блиских језичких образаца.

${ }^{1}$ За детаљнији опис и анализу класе $C$ у контрастивној перспективи српско-енглеској перспективи видети Герке (Gehrke 2008) и Миливојевић 2016a, $2016 \mathrm{~b}$. 


\section{2. ТЕОРИЈСКИ ОКВИР ИСТРАЖИВАЬА}

Централно теоријско полазиште нашег истраживања је пројекционистичко-конструкционистички лингвистички модел који је заснован на примарним лексичким, морфолошким и синтаксичким својствима глагола стварања звука. Овакав приступ удружује почетни лексичко-пројекционистички модел Бет Левин (в. Levin 1993) за организовање глагола у семантичке класе на основу њиховог примарног значења и синтаксичке структуре аргумената, са граматиком конструкција (в. Goldberg 1995). Такође, као што је раније наведено узима се у разматрање Талмијева типолошка класификација природних језика која језике разврстава у класе према прототипским начинима кодирања простора и просторних релација.

\section{1. Преглед досадашњих повезаних истраживања о српском језику}

У својој студији Једно поглавље из граматике нашег савременог језика - систем месних падежа (1957), Милка Ивић успоставља јасну разлику између контактних и неконтактних падежних конструкција. За разлику од оријентационих (неконтактних) падежних конструкција, контактне падежне конструкције садрже контактну сему. Контактна сема конкретизује се путем различитих типова контактности (унутрашња, површинска и неспецификована). Према Пиперу (уп. Пипер 2001: 68-69) директивна сема дефинише синтагматски капацитет просторне падежне конструкције, тј. њену отвореност за комбиновање са одговарајућим типом глагола који се налази на позицији управног предиката. Директивна сема може бити остварена као директивност или као индирективност, при чему се директивност конкретизује као аблативност (или стартна усмереност), перлативност (или линијска усмереност) или адлативност (циљна усмереност). Значајне студије које се баве функцијом и значењем префикса на нивоу синтагме су студије Милоша Ковачевића Префиксација и њен утииај на форму и семантику синтагме (1986.) и Кроз синтагме и реченице (1992). Надаље, једна важна когнитивистичка теорија коју је у лингвистичким проучавањима везаним за српски језик артикулисао Предраг Пипер у својим студијама Обележавање просторних односа предлошко-падежним конструкцијама у савременом руском и савременом српскохрватском книжевном језику (1977-1978) и Језик и простор (2001), данас је темељ за надограђивање и продубљивање сличних истраживања у србистичкој литератури. Сличном линијом анализе крећу се, на пример, Душка Кликовац у студијама Семантика предлога: Студија из когнитивне лингвистике (2000) и Метафоре у језику и мишьеьу (2004), затим Ивана Антонић у монографији Временска реченица (2001) и Катарина Расулић у монографији Језик и просторно искуство: Концептуализација вертикалне димензије у енглеском и српскохрватском језику 
(2004) као и многи други. Још једну теоријску перспективу која се тиче пре свега синтаксе и семантике глагола и глаголске фразе којом се изражава кретање понудио је Предраг Новаков у својој контрастивној студији о аспекту (посматрају се енглески и српски језик у контрасту), под насловом Глаголски вид и тип глаголске ситуаиије (Новаков, 2005). У овој студији наглашава се да је однос језика, простора и кретања доминантно кодиран управо у домену глаголске фразе. Новаков се бави и специфичним значењима партикула, префикса и предлога у енглеском и српском језику, наглашавајући њихову функционалну еквивалентност у два посматрана језика, са посебним освртом на граматички и лексички аспект безпрефиксалних и префиксалних глагола на нивоу глаголске фразе.

\section{2. Језичка типологија према Ленарду Талмију}

Једна од најутицајнијих теорија на пољу међујезичких истраживања која се везују за однос језика и простора те за изражавање кретања у природним језицима јесте језичка типологија Ленарда Талмија (Талму 1991, 1994, 2000) која сврстава језике у типолошке класе на основу тога како је различитим морфо-синтаксичким и семантичким средствима у језику могуће исказати лингвистички догађај кретања. Ситуативни оквир догађаја кретања сачињен је од устаљених елемената и односа који су карактеристични за семантичку категорију простора ${ }^{2}$. Овако дефинисан ситуативни оквир близак је појму конструкције, док је Талмијева језичка типологија по својој теоријској суштини изразито конструкционистичка. Сваки догађај кретања обавезно садржи следеће елементе: објекат локализације, локализатор, путању и кретање. ${ }^{3}$

У низу Талмијевих истраживања иницијално су установљена два основна типа природних језика; језици су се сврставали у две типолошке класе и то су били језици са глаголским (енг. verb-framed languages) и језици са сателитским ситуативним оквиром (енг. satellite-framed languages). ${ }^{4}$ Но емпиријска

${ }^{2}$ Како наводи група аутора Пипер и други (Пипер и др. 2005:719) да би одређена семантичка категоријаија била доследно и граматички правилно исказана у језику, језичке ситуације којима се она изражава треба да имају одређени ситуативни оквир.

${ }^{3}$ Објекат локализације је ентитет који се креће или пак ентитет који се лоцира у односу на други спецификовани ентитет - локализатор. Кретағе је инхерентна карактеристика догађаја кретања. Путањ $а$ је или правац у ком се објекат локализације креће, или простор по ком се објекат локализације креће у односу на локализатор. Додатно, начин и узрок кретањ $а$ посматрају се као одвојени поддогађаји који могу у форми придруженог догађаја бити придодати догађају кретања у оквиру укупног, макро-догађаја.

${ }^{4}$ Језици са глаголским ситуативним оквиром (на пример италијански и шпански) путању инкорпорирају на лексичко-творбеном плану глаголске лексеме, док језици са сателитским ситуационим оквиром (на пример енглески и српски) путању кретања лексикализују сателитима, а то су најчешће партикуле, предлози или предлошке фразе и то изван непосредног семантичког домена управног предиката. 
истраживања нешто новијег датума која су спроведена у оквру значајног броја различитих природних језика показала су да оваква стриктно дефинисана двосмерна типологија није довољна да објасни изразито комплекснио и разуђено понашање природних језика по питању односа језика, простора и кретања, па се у литератури приступило преиспитивању њених најважнијих поставки и критеријума. ${ }^{5}$

Како наводи група аутора Биверс и др. (Beavers et al. 2009): само посматрање централне шеме догађаја кретања није довољно за јасну типолошку класификацију природних језика; потребно је проверити релевантне типолошке одлике различитих језика на већем броју конструкција; такође, уместо установљавања језичких типова, боље је говорити о језичким тендецијама јер се тиме оставља простор за сагледавања изузетака и атипичног понашања појединих језика.

Један за наше истраживање изразито важан допринос ревизији Талмијеве типологије предложен је у оквиру студије групе аутора Крофт и др. (в. Croft et al. 2010): префикси су такође сателити, исто као предлози и партикуле; коначно, префикси заједно са предлозима и партикулама чине класу $C$, или класу сателита у енглеском језику. Крофт појам сателита дефинише на следећи начин: сваки елемент конструкције који није лексички корен глагола а којим се кодира нека компонента догађаја кретања је сателит (в. Croft et al. 2010). ${ }^{6}$ У оквиру ове студије задржава се теза о могућем разуђеном понашању једног истог језика под специфичним околностима. Поврх тога, наглашава се и веома велики значај концептуалног знања говорника при интерпретацији конструкције, као и фреквентност или устаљеност употребе одређене конструкције унутар датог језичког система. За разлику од ранијих верзија Талмијеве типологије, овде се истиче да је концептуално знање говорника или његово знање о свету додатно значајан фактор у селекцији и варирању граматичке,

5 Занимљиво је, на пример да, упркос томе што српски и енглески језик припадају истом типу језика са сателитским ситуативним оквиром, српски језик, за разлику од енглеског, нема морфо-синтасички потенцијал за исказивање придевских резултатива (енг. adjectival resultatives) као у енглеским реченицама Mary hammered the metal flat или Peter closed the window shut; оваква значења у српском се реализују префиксалним глаголима и другим средствима, што опет неке ауторе (Gehrke 2008, Beavers et al. 2009, Croft et al. 2010) наводи на закључак да је потребно увести додатне параметре у циљу исцрпније и прецизније типологизације природних језика. Насупрот томе, у енглеском језику није доступна конструкција са значењем двоструког кретања као у реченици Петар је певао улицом, где се емитер звука и звук истовремено крећу (в. Jackendoff 1990, 1997, Culicover and Jackendoff 2005).

${ }^{6}$ Иницијално у оквиру поделе језика према Талмију, предлози нису посматрани као сателити. Талми наводи да сателит може бити било који конституент глаголског догађаја изван именичке и предлошке фразе који стоји у сестринској релацији са кореном глагола. То су, на пример, глаголске партикуле у енлеском, префикси у немачком, руском и латинском, комплементи глагола у кинеском итд. 
семантичке и прагматичке прихватљивости истоветнох структура које садрже различите лексичке јединице.

\section{3. КЛАСА ГЛАГОЛА СТВАРАњА ЗВУКА И ЊЕНЕ СПЕЦИФИЧНОСТИ}

Полазна тачка за успостављање српске класе глагола стварања звука коју проучавамо у овој студији јесте енглеска класа глагола стварања звука која је сакупљена и објављена у студији Бет Левин (Левин 1993) под насловом English Verb Classes and Alterantions. ${ }^{7}$ Почетна класа глагола према Бет Левин је за потребе овог истраживања модификована због временске дистанце од датума објављивања студије до данас. Актуелни статус и релевантност новоизоловане класе класе глагола стварања звука те њихова заступљеност у употреби у савременом енглеском језику проверени су у доступним лексикографксим изворима, као и у електронској лексичкој мрежи Ворднет (Wordnet) ${ }^{8}$.

Енглески глаголи стварања звука лексикализују стварање и емитовање звука. ${ }^{9}$ Левин такође наводи скуп доступних структура аргумената за ове глаголе у енглеском језику: они се јаљају како у оквиру неергативних (енг. unergative) (пример 2a), тако и унутар неакузативних (енг. иnaccusative) образаца на синтаксичком нивоу (пример 2б) ${ }^{10}$ :

2.

a) Peter shouted. (српски: Петар је викао.)

б) The cart rumbled down the street. (српски: Кола су клопарала низ улицу.)

У реченици 2а, субјекат глагола је истовремено и емитер звука, док је у примеру 26 звук последица неке друге радње, или, прецизније речено, звук је

${ }^{7}$ Основна хипотеза овог истраживања била је да се понашање глагола, посебно по питању везивања и интерпретације аргумената које глагол пројектује у оквиру припадајуће шире структуре и језичког исказа, у највећој мери може предвидети на основу његовог лексичког значења.

${ }^{8}$ Списак штампаних и електронских извора дат је на крају рада.

9 Звук који се лексикализује овим глаголима може долазити из вокалног тракта човека, може означавати оглашавање животиња или може лексикализовати звук који стварају различити артефакти под различитим дефинисаним околностима.

${ }^{10}$ Према хипотези о неакузативности (енг. Unaccusative Hypothesis) у литератури постоји подела интранзитивних глагола на неакузативне и неергативне (в. Perlmutter 1978, Burzio 1986, Levin \& Rappaport Hovav 1995). Левин и Рапапорт-Ховав (в. Levin \& Rappaport-Hovav 1995) наводе да неергативни, као и неакузативни глаголи имају само један спољашњи синтаксички аргумент. Оно што разликује ова два подтипа непрелазних глагола јесте почетна позиција у синтакси на којој се налази спољашњи аргумент глагола. Спољашњи аргумент неергативног глагола генерише се на позицији синтаксичког субјекта, док се спољашњи аргумент неакузативног глагола генерише на позицији објекта, односно унутар објекатског комплемента у односу на глагол. 
директна последица кретања и настаје као производ контакта између објекта локализације и локализатора. Звук се лексикализује као начинска компонента кретања, док се структурна интерпретација кретања означеног звуком јавља на нивоу укупне конструкције, захваљујући предлошкој фрази down the street којом се дефинише трајекторија по којој се креће објекат локализације the cart. $^{11}$

\section{1. Класа глагола стварања звука у српском језику}

Када је реч о глаголима стварања звука у српском језику, кренуло се од успостављања лексичке класе на основу такве класе глагола у енглеском језику, да би се потом структурно понашање добијених глаголских лексема испитало у оптималном језичком контексту ${ }^{12}$, тј. на нивоу реченице. Лексичка класа српских глагола стварања звука укључује преводне еквиваленте енглеских глагола, онако како су они забележени и пронађени у лексикографским изворима који су консултовани у сврху овог истраживања. ${ }^{13}$ Провером лексикографских извора те упоређивањем добијених лексичких уноса са класом глагола стварања звука у енглеском језику изолована је класа српских глагола стварања звука која је дата у табели (3):

11 За шири опис ове класе глагола у енглеском видети Левин (Levin 1993), Миливојевић 2016а, $2016 б$.

${ }^{12}$ Прћић (1997: 28) конкретно каже: „Оптимални контекст, онај који обично пружа реално довољно потребних података налази се, очито, између ове две крајности - то је најчешће, иако не увек, реченица, као део текста, што указује на извесну предност максималистичког приступа, али његове флексибилно и осмишљено редуковане варијације.”

${ }^{13}$ Обухваћени су и глаголи са афиксима, односно полиморфне глаголске лексеме без обзира на то да ли појединачни афикси уводе или не уводе ново лексичко значење глагола. Глаголи са афиксима задржани су зато што њихово присуство у речницима додатно расветљава синтаксичку дистрибуцију глагола стварања звука у оквиру неакузативних и неергативних конструкција, унутар теличних и ателичних фраза, и коначно унутар конструкција којима се исказује директивно кретање у српском језику. 


\section{4. ГЛАГОЛИ СТВАРАњА ЗВУКА У СРПСКОМ ЈЕЗИКУ}

\begin{tabular}{|c|}
\hline Класа српских глагола стварања звука (134 глаголске лексеме) \\
\hline 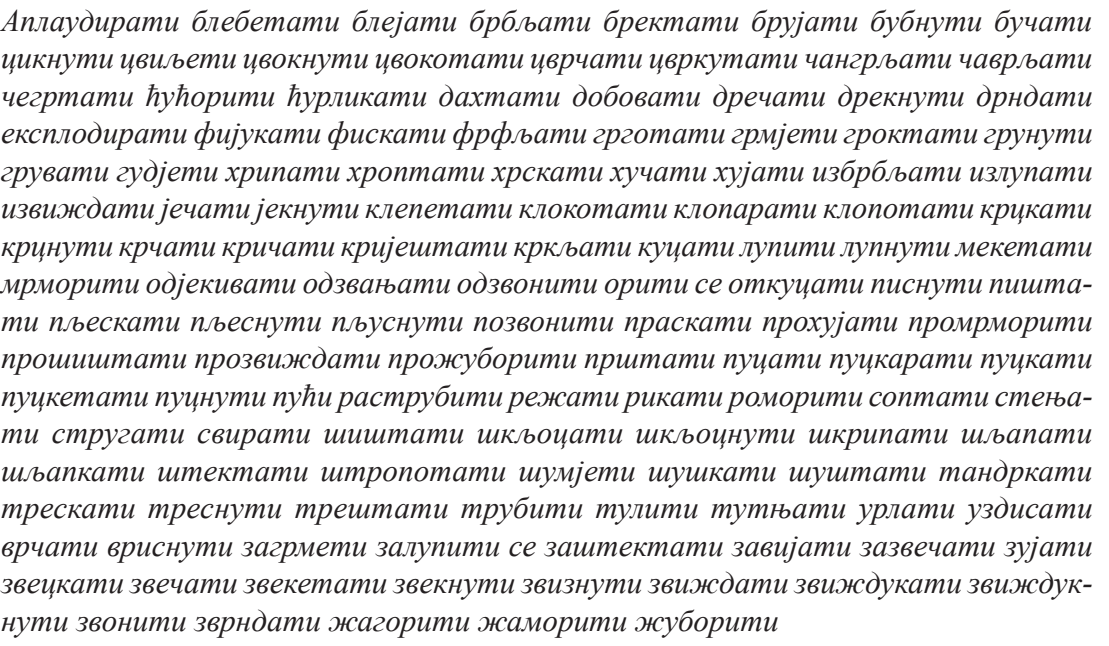 \\
\hline
\end{tabular}

\section{2. Структура и организација реченичног корпуса}

За потребе нашег истраживања сачињен је реченични корпус који садржи укупно 210 реченичних примера аутентичних реченица на српском језику. Реч је о комбинованом реченичном корпусу који је делом ексцерпиран из шест књижевних дела и то оригиналних романа на српском језику аутора Живојина Павловића (укупно 95 примера) ${ }^{14}$, док је други део корпуса сачињен претраживањем електронског корпуса Савременог српског језика (укупно 115 примера). Полазна основа за претраживање књижевне језичке грађе и електронског корпуса Савременог српског језика била је класа глагола стварања звука коју смо дефинисали у одељку 3.1. Сажети приказ структуре реченичног корпуса дат је у табели (4):

${ }^{14}$ Списак књижевних извора дат је на крају рада. 


\section{5. КОМБИНОВАНИ РЕЧЕНИЧНИ КОРПУС (210 PRIMERА) $)^{15}$}

\begin{tabular}{|c|c|}
\hline $\begin{array}{c}\text { Књижевни корпус српског језика }- \\
\text { ККС }\end{array}$ & $\begin{array}{c}\text { Електронски корпус } \\
\text { Савременог српског језика }- \text { ЕКС } \\
115 \text { примера }\end{array}$ \\
\hline 35 примера & \\
\hline 3С (22 примера $)$ & \\
\hline ЗТ (25 примера) & \\
\hline РМ (8 примера) & \\
\hline ЛТ (20 примера) & \\
\hline ДВ (12 примера) & \\
\hline АЗ (8 примера) & \\
\hline
\end{tabular}

\section{6. СТРУКТУРНА И СЕМАНТИЧКА КЛАСИФИКАЦИЈА КОНСТРУКЦИЈА ДИРЕКТИВНОГ КРЕТАҢА СА ГЛАГОЛИМА СТВАРАњА ЗВУКА У СРПСКОМ ЈЕЗИКУ}

Директивно кретање је вид кретања код ког је могуће одредити правац или циљ кретања те дефинисати трајекторију по којој се креће објекат локализације. Директивно кретање најчешће подразумева промену локације у простору или другу повезану промену која је блиска кретању, а која се може очитовати било као поменута промена просторне локације, било као промена неког значајног својства партиципаната догађаја кретања. Конструкције којима се изражава директивно кретање везују се за нехомогену структуру dozaђаја (енг. temporal structure) и по својој семантици блиске су транзитивним конструкцијама са значењем резултата ${ }^{16}$. Директивно значење (као подоблик циљног значења) је само по себи сложено и по правилу се наставља на нека друга категоријална значења, без обзира на језичка средства којима је изражено и то су на пример аниматност, узрок, услов, агентивност, темпоралност и томе слично. Најчешћи елементи конструкције су објекат локализације (ОЛ),

\footnotetext{
${ }^{15}$ У раду ћемо цитирати реченице из корпуса, као и један део реченичних примера који су прикупљени из литературе или су одабрани као преводни еквивалентни релевантних реченица на енглеском језику које су значајне за нашу анализу, дискусију и закључке.

${ }^{16}$ Значење резултата блиско је повезано са течичношћу - у оквиру овог рада задржаћемо се на значењу резултата које се у конструкцијама које су предмет наше анализе најчешће очитује као промена локације у простору.
} 
локализатор (Л), конкретизатор просторне релације (К) и трајекторија (или путања) кретања (П).

Посматрано „са површине”, начин на који се звук манифестује као кретање у српском језику исказује се низом структурно блиских конструкција и To cy:

А) Права емисија звука: у оквиру оваквих конструкција, синтаксички субјекат реченице је истовремено семантички агенс и емитер звука. Када је реч о правој емисији звука, нагласићемо да ове конструкције немају значење „звук уместо кретања". Права емисија звука означава искључиво кретање звука као производа емитовањ $а$, а не звука као последице кретања. На пример:

5. Јован виче (из куће); Петар пева (са прозора); Гитара јеца (у тами); Воз звижди (у станици).

Примери из корпуса су:

6. Са балкона виче и маше ми марамом (ДВ); Са планина урлају вукови (A3).

Прототипски глаголи стварања звука којима се изражава права емисија звука најчешће су глаголи којима се лексикализује звук који долази из вокалног тракта човека (викати, певати, дахтати и сл.). Додатни услов за реализацију овакве конструкције јесте својство агенса које се у литератури најчешће бележи као аниматност или вољност. Међутим, у корпусу се јављају и такви примери са неаниматним субјектом, где није реч о аниматном агенсу, али се конструкција упркос томе јавља са неергативним синтаксичким обрасцем. Примери из корпуса су:

7. Авион бруји изнад нас, невидљив у облацима. (ЕКС); С ону страну ограде дашћу ниске локомотиве сличне јазавичарима... (3С).

У складу са анализом коју предлажу Фоли и Харли (Folli \& Harley 2008) на примерима из енглеског језика и Миливојевић (2010а) на примерима из српског језика, усвојићемо теоријску поставку према којој агенс може бити сваки ентитет који има способност да самостално иницира и произведе глаголски догађај стварања звука. Следеће питање на које је потребно понудити одговор јесте која је то особина инаниматног агенса која га чини и семантички адекватним, будући да својства интенционалност и аниматност у поменутим случајевма изостају. Како наводе Фоли и Харли „иако столови и возови нису аниматни ентитети, они поседују одређене особине својствене њиховој унутрашњој конструкцији, које их чине погодним енитетима који звижде или шкрипе. Возови заправо имају у себе уграђене пиштаљке, а столови шкрипе због карактеристика властитих конструкција.” (Folli \& Harley 2008: 192). Фоли и Харли ово значајно својство инаниматних агенаса називају телеолошки капацитет 
(енг. teleological capacity). Кључна особина која начелно одликује семантичке агенсе према томе није аниматност већ телеолошки капацитет ентитета на синтаксичкој позицији субјекта да самостално генерише радњу од почетка до краја. Закључићемо да је права емисија звука са глаголима стварања звука у српском језику могућа како са аниматним тако и са инанимантним агенсима и да се у оба поменута случаја на синтаксичком нивоу конструкција формално реализује на исти начин: глагол стварања звука на позицији управног предиката везује спољашњи аргумент (субјекат), а цела конструкција реализује се путем неергативног синтаксичког обрасца, без обавезног присуства сателита.

Б) Двоструко кретање: у овим ситуацијама постоје два ентитета која се истовремено крећу и то су емитер звука и сам звук. Два глаголска догађаја кретања су у темпоралној вези, они су паралелни и истовремени, али у формалном смислу не зависе један од другог, тачније међу њима не постоји каузална веза. На пример:

8. Петар је гласно певао низ улии;; Камион је трубио кроз тунел/улииомл/по улици/према зградии.

Конструкције са значењем двоструког кретања које се у српском језику могу јавити и са аниматним и са инаниматним агенсима нису доступне у енглеском језику. ${ }^{17}$ Еквивалентниом синтаксичком структуром у енглеском језику могуће је означити искључиво праву емисију звука, или кретање самог звука, без придруженог кретања емитера звука. У том смислу, српски језик испољава нешто виши степен „слободе” када је реч о исказивању кретања глаголима стварања звука. Примери из корпуса су:

9. Поред тога, обновљена је пруга уског колосека којом стари , добри „ћира” брекће између железничке станице и старе Фабрике каблова... (ЕКС); Брекће парњача низ насип; из ракиту се примећива само дим. (3T).

Као што показују примери (9), значење двоструког кретања структурно се изражава неакузативном синтаксом. Ако погледамо контраст између примера $10 \mathrm{a}$ и 10б, можемо закључити да је присуство предлошко-падежног комплемента на нивоу конструкције неопходно за исказивање двоструког кретања, што није случај са конструкцијама којима се изражава права емисија звука:

10.

a) Јован је певао./Јован је певао (са прозора). (права емисија звука)

б) Јован је певао низ улицу. (двоструко кретање)

17 За детаљну дискусију о двоструком кретању у енглеском језику видети Левин 1998, Каликавер у Џекендоф 2005, Миливојевић 2010а, 2016а, 2016 . 
В) Звук уместо кретања: за разлику од конструкција са значењем двоструког кретања, овде је реч о звуку који је директна последица кретања или о звуку који настаје услед специфичног начина кретања. У оквиру конструкција директивног кретања којима се одражава значење „звук уместо кретања", једини начин да дође до стварања или производње звука јесте да постоји ентитет који се креће тако да то кретање производи звук. Такође, између између кретања и стварања звука постоји дефнисана темпорална и каузална веза; често постоји физички конакт између објекта локализације и локализатора (на пример, постоји контакт између самог објекта који се креће и површине по којој се тај објекат креће). Овакве конструкције директивног кретања остварују се путем неакузативне синтаксичке структуре и биле су најбројније у нашем корпусу.

11. А воз је тутьао насипом; примицао се железном мосту преметнутом преко Тимока и сопћући и дахћући смағивао брзину, да би се уз шкрипу кочница и звекет одбојника зауставио у железничкој станици на чијем је прочељу писало: Вратарница. (А3); Враћајући се у ћумез, срео сам се са Соњом... прозвиждала је поред мене по коси изнад Жујана, изгубивши се у вејавици као привиђење. Пре но што је замакла за хоризонт, подигла је скијашки штап у знак поздрава. (ЛТ); Калдрмом, покрај бивше Аронове апотеке, ваљала су се и тандркала сељачка кола са старицама поврх врећа с купусом или кромпиром. (ЛТ); Лешници су добовали по крову и котрљали се низ uреп.(ЕКС); Али, како је колона кретала, тако су по њој фијукала снајперска зрна, а ватра је оживљавала (ЕКС).

Важно је нагласити да правилна интерпретација конструкције директно зависи од присуства предлошко-падежне синтагме, уз могуће (али не и обавезно) присуство префикса на главном глаголу. Наиме, будући да глаголи стварања звука примарно не лексикализују кретање, лескикализација трајекторије постиже се на нивоу конструкције, путем пројектоване структуре аргумената. Осврнућемо се сада на следећи низ примера:

12.

a) Метак је прозвиждао кроз прозор.

б) ?Метак је прозвиждао.

в) ??Метак је звиждао. (у месту)

в) Глисер је шљапкао поврх таласа.

г) ?Глисер је прошљапкао (поред нас).

д) ??Глисер је шљапкао. (у месту) 
Оно што настојимо да илуструјемо низом примера 12a-д јесте структурни и семантички континуум којим су обухваћене конструкције директивног кретања са непрототипским управним предикатом. Наиме, степен граматичке и семантичке прихватљивости конструкције, као и њена правилна интерпретација директно зависе од присуства сателита којима се лексикализује и спецификује правац и/или циљ кретања. Будући да конструкције са неакузативном синтаксом не везују прави субјекат, тј. семантички агенс, не може се говорити о агентивности нити о телеолошком капацитету спољашњег аргумента управног предиката да сам генерише и/или контролише радњу именовану глаголом. Меци звижде искључииво приликом кретања кроз ваздух, а глисери шљапкају искључиво у контакту са водом. У примерима 12а-д звук је последица кретања, тј. до стварања звука долази реализацијом догађаја кретања под специфичним околностима које се лексикализују класом сателита и то глаголским префиксима и предлошко-падежним синтагмама.

Г) Метафорично кретање праћено звуком: у овим ситуацијама глагол стварања звука описује метафорично кретање. Конструкција се на синтаксичком нивоу може реализовати путем оба синтаксичка обрасца, тачније она може бити и неергативна и неакузативна и подлеже истоветним морфо-синтаксичким ограничењима као и оне конструкције којима се реализује неки од три претходно објашњена типа значења. На пример:

13. Минути и секунде... фијучу око мене шибајући ме као камџија. (ДВ); Дамар живота куца свежим током између ксенофобије и клаустрофобије (ЕКС); Смрт прашти из тенкова, из бомбардера. (ЕКС).

\section{7. ЕЛЕМЕНТИ КЛАСЕ С У СРПСКОМ ЈЕЗИКУ}

Класа сателита представља кључни основ за класификацију природних језика према Талмију. Као што је раније истакнуто, елементи класе сателита или класе $C$ у српском језику чине скуп морфо-лексичких језичких јединица којима се лексикализује трајекторија по којој се креће објекат локализације у оквиру догађаја директивног кретања. Елементи који у српском језику припадају класи сателита директно утичу на реализацију контрукције директивног кретања у ситуацији када управни глагол не припада семантичкој класи глагола кретања. Будући да српски језик према Талмијевој типологији припада језицима са сателитским ситуативним оквиром, класа С омогућава да се непрототипским глаголима означи кретање или просторни однос, јер се непотпуна лексичка спецификација глагола „допуњава” управо путем елемената класе $\mathrm{C}$.

Да би информација о неком просторном односу била потпуна, однос између објекта локализације и локализатора, ближе се одређује посебним 
елементом у ситуативном оквиру коонструкције - оријентиром (Пипер и др. 2005:719.) На пример, у реченици Свеска је на књизи, конкретизатор просторног односа, или оријентир је предлог на. У српском језику, поред предлога, важно је поменути још и глаголске префиксе и падежне суфиксе. У прототипској реализацији конструкције директивног кретања са глаголом стварања звука у српском језику, јавља се глагол са префиксом. ${ }^{18}$ Коначно, у српском језику, глаголски префикси у оквиру конструкције којом управља глагол стварања звука улазе у дефинисане интеракције са предлозима и падженим суфиксима што отвара (али и ограничава) морфо-синтаксичке могућности за исказивање низа сродних конструкција директивног кретања.

\section{1. О структурним и семантичким ограничењима конструкције директивног кретања са глаголима стварања звука}

Класа сателита на значајан начин утиче на граматичку и семантичку прихватљивост са једне, те на продуктивност конструкција директивног кретања са глаголима стварања звука са друге стране. Ове конструкције значајно су продуктивније када се трајекторија кретања лексикализује сателитима (предлозима и/или префиксима) са значењем правиа (најчешће је то комбинација префикса и предлога про-кроз), него онима са значењем циља. Такође, директивне конструкције у којима предлог и префикс семантички лексикализују исту скалу, тј. имају исто значење, не подлежу ограничењима по питању структуре и интерпретације конструкције (примери 14a), док то може бити случај када се префикс комбинује са предлогом чије значење није усклађено са основним значењем префикса ${ }^{19}$ (пример 14д). Овакво ограничење последица је чињенице да природа трајекторије по којој се креће објекат локализације такође утиче на граматичку и семантичку прихватљивиост укупне конструкције (в. Zwarts 2005, 2006, Gehrke 2008, Миливојевић 2016б). Поврх тога, у оквиру конструкција са значењем двоструког кретања које испољавају примарно неакуазитвну синтаксу, јављају се ограничања по питању префиксације глагола стварања звука чак и у случајевима када су префикс и предлог семантички „паралелни” (примери 14в, 14г). Пример 14б, са друге стране, показује да је могуће комбиновати префикс и предлог који нису семантички паралелни, под условом да им значења нису супротна, као и да оријентир може бити контекстуално дат путем конкретизатора поред.

\footnotetext{
${ }^{18}$ Постоје бројни аргументи у литератури о томе да су префикси у српском језику (и у словенским језицима уопште) и партикуле и предлози у енглеском сродне и функционално еквивалентне класе елемента (Brinton 1988, Novakov 2005, Arsenijević 2007, Миливојевић 2007.).

${ }^{19}$ Формална синтаксичка анализа конструкција директивног кретања је изван оквира овог истраживања; за детаљнију и формалнију расправу о овом проблему видети Миливојевић 2016a.
} 
14.

a) На скијама су прозвиждали кроз шуму.

б) На скијама су прозвиждали поред шуме.

в) ??На скијама су дозвиждали до шуме.

г) ??На скијама су извиждали из шуме.

д) *На скијама су извиждали до шуме.

Примери 15a-15д илуструју исто понашање конструкција директивног кретања са значењем ,звук уместо кретања”:

15.

a) Метак је просвирао кроз прозор.

б) Метак је просвирао поред нас.

в) ??Метак је усвирао у собу.

г) ??Метак је усвирао поред нас.

д) *Метак усвирао из собе. ${ }^{20}$

Овде је потребно одговорити на два питања: 1) који партиципант догађаја кретња везује „главну” трајекторију ${ }^{21}$ и 2) под којим условима је могуће квантификовати догађај кретања, тако да се не наруши граматичка и семантичка прихватљивост конструкције. Када је реч о чистој емисији звука, тј. када је објекат локализације само звук без додатног кретања ентитета који тај звук емитује или ствара, глагол се по правилу не јавља са префиксом:* Јован је пропевао кроз кућу. Очигледан формални разлог за овакво граматичко понашање конструкције може да лежи у чињеници да овде предлошко-падежна синтагма није обавезни аргумент глагола, тј. реченица је граматична и без експлицитно лексикализоване трајекторије кретања, дакле за њену правилну реализацију није неопходно присуство сателита. Додатно, као што је наведено у дискусији у претходном одељку текста, конструкције са значењем двоструког кретања обухватају две скале или трајекторије кретања: прва је трајекторија по којој се креће емитер звука, а друга она по којој се креће сам звук. Ове две скале стапају се конфлаиијом (енг. path conflation), но будући да скала кретања звука не означава физичко кретање, није је могуће квантификовати омеђеним сателитима чија примарна денотација по правилу лексикализује односе везане за физички простор. Додатни проблем представља и то што је управо

${ }^{20}$ Осим са интерпретацијом где предлог означава локацију са које долази метак, а не трајекторију по којој се он креће.

${ }^{21}$ Према Хагит Борер (Borer 2014), један глаголски догађај може да веже само једну скалу кретања на синтаксичком нивоу. 
стварање звука овде поддогађај кретања који је примаран, док је физичко кретање придружени или осенчени (енг shadowed) поддогађај - примарно лексичко значење стварања звука доминантније утиче на укупно граматичко понашање конструкције, иако је њена семантичка интерпретација усмерена на означавање просторног кретања. ${ }^{22}$

Осим префикса и предлога, још један елеменат класе $\mathrm{C}$ који је значајан за нашу анализу је падежни суфикс. Формално посматрано, предлози учесницима глаголског догађаја приписују падежна обележја, тј. они додељују падеж својим именским комплементима. У сфери просторне адвербијалне детерминације српски акузатив је директивно маркиран падеж, будући да је компатибилан искључиво са директивним глаголима, те се у том смислу може јавити и код кинетичких спацијалних категорија (често код перлативности). Спацијални акузатив у српском језику по правилу је „блокиран” предлогом. На пример:

16.

a) Грми мотоцикл кроз баре и глиб ${ }_{\text {acc }}(\mathrm{PM})$

б) Испод реторте гори примус; кроз тек отворену пукотину асс шишти жућкаста пара, ширећи по просторији задах сумпордиоксида. (251)

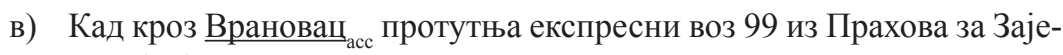
чар. (3Т)

г) На прозор слете голуб, гугутну, прхну на шталу acc $^{.}(160$ 3Т)

У српском језику истоветно значење може се изразити и инструменталом који се додаје на именицу која описује ентитет на који се пресликава путања кретања. У примерима 17а-19в нема експлицитно израженог предлога већ се интерпертација директивног кретања постиже само путем падежног наставка, што додатно потврђује нашу хипотезу о томе да падежним суфиксима у српском језику треба доделити равноправан статус сателита, уз префиксе и предлоге:

17.

a) Јован је викао улицом ${ }^{23}$ instr

б) Калдрмом сељачка кола са старицама поврх врећа с купусом или кромпиром. (ЛТ)

${ }^{22}$ Конструкције са значењем метафоричног кретања подлежу истоветним структурним и семантичким ограничењима као и остала три типа конструкција директивног кретања са глаголима стварања звука, зависно од тога да ли се испољавају путем неергативног или неакузативног синтаксичког обрасца.

${ }^{23}$ Пример је преузет од Миливојевић $2016 \mathrm{a}$. 


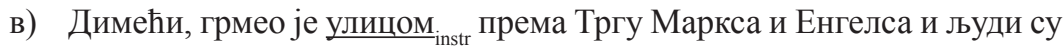
га равнодушно гледали. (ЕКС)

Корпус на ком је спроведен емпиријски део нашег истраживања садржи и примере у којима је трајекторија кретања делимично лексикализована именицом у локативу, што је поново ентитет на који се пресликава путања кретања:

18.

a) Трамвај је клопарао по блештавим шинама ${ }_{100} \ldots$ (ЕКС)

б) Лешници су добовали по крову ${ }_{\text {loc }}$ и котрљали се низ цреп. (ЕКС)

в) Док је стари форд бректао у првој брзини по џомбастом путу $_{\mathrm{loc}} \ldots($ ЕКС)

Следећи низ примера илуструје значај енциклопедијског знања говорника, односно његовог знања о свету (енг. world knowledge) при употреби и интерпретацији конструкција директивног кретања. ${ }^{24}$ Ограничења која су илустрована примерима 19в и 19г проистичу из концептуалне природе именице која се налази у улози локализатора. Реченица је прихватљива само уколико се локализатор означава просторном именицом, као што се види на основу примера 19а и 19б. Примери 19а-19г су инстанце конструкције директивног кретања са значењем двоструког кретања:

19.

a) Јован је викао улицом instr

б) Јован је викао по кући loc $_{\text {. }}$

в) *Јован је викао прозором instr $_{\text {. }}$

г) *Јован је викао по прозору ${ }_{\text {loc }}$.

Премда је оваква и слична просторна значења и просторне односе могуће лексикализовати и другим падежним суфиксима у српском језику, овде смо анализу усмерили само на оне предлошко-падежне синтагме које су се појавиле у нашем реченичном корпусу. Сматрамо да је корпусом јасно илустровано понашање српског језика по питању конструкција директивног кретања са глаголима стварања звука, као и да се на основу примера који су анализирани у нашој студији могу извести доследни закључци како о реле-

${ }^{24}$ Како наводе Пипер и др. (2005:718) „будући да су просторна значења заступљена у скоро свим врстама речи, велики број именица има конктретно-просторна значења, што је услов да те именице могу бити употребљене у синтаксичким конструкцијама за обележавање просторних односа, као речи којима се у таквим односима именује локализатор." 
вантним граматичким и семантичким параметрима, тако и о ограничењима који се на те конструкције примењују.

\section{8. ЗАКЉУЧНЕ НАПОМЕНЕ}

Ова анализа представља покушај да се са теоријског аспекта доследно опишу и класификују конструкције директивног кретања са глаголима стварања звука у српском језику. Посматрање конструкције на реченичном корпусу имало је за циљ са једне стране емпиријску потврду теоријских хипотеза које су постављене на почетку анализе, а са друге додатни увид у језички потенцијал за реализацију ових конструкција у српском језику.

Конструкције директивног кретања класификоване су прво према испољеној синтаксичкој структури (неергативни и неакузативни синтаксички образац), а потом и према семантичкој интерпретацији где су установљена четири типа значења (права емисија звука, двоструко кретање, значење ,звук уместо кретања" и метафорично кретање). Посебна пажња у оквиру наше анализе усмерена је на класу сателита, или класу $C$. Показано је да сателити у српском језику обухватају префиксе, предлоге и падежне суфиксе. Питања којима би се могла бавити слична будућа истраживања су: које семантичке класе глагола које су блиске глаголима стварања звука такође могу да се нађу на позицији управног предиката конструкције директивног кретања (потенцијално, то су глаголи стварања светлости и глаголи стварања супстанце) и која би била структурна и семантичка ограничења при реализацији таквих конструкција у српском језику. Истраживања која се крећу у овом правцу доприносе ширем и јаснијем сагледавању системског понашања различитих природних језика по питању кодирања и конкретизовања просторних односа и просторних релација у оквиру типолошких класификација каква је Талмијева типологија.

\section{ИЗВОРИ}

\section{Електронски извори}

Електронски корпус Савременог Српског језика Природно-математичког факултета у Београду http://korpus.matf.bg.ac.rs 10.2.2016.

Corpus of Contemporary American English (COCA) http://corpus.byu.edu/coca/ 10.2. 2016.

Britsih National Corpus (BNC) http://www.natcorp.ox.ac.uk/ 10.2.2016.

Wordnet. A Lexical Database for English https://wordnet.princeton.edu/ 10.2.2016. 


\section{Штампани извори}

English Serbian or Croatian Dictionary. Benson, Morton, uz saradnju Biljane Šljivić Šimšić (drugo prerađeno i dopunjeno izdanje). Beograd: Prosveta. 1988.

English Croatian or Serbian Dictionary (у редакцији Рудолфа Филиповића). Загреб: Школска књига. 1996.

Велики енглеско-хрватски рјечник. Бујас, Жељко. Загреб: Накладни завод Глобус. 2005.

Павловић, Живојин. Зид смрти. Београд: Просвета. 1985.

Павловић, Живојин. Задах тела. Београд: Београдски издавачко-графички завод. 1985.

Павловић, Живојин Расло ми је бадем дрво. Београд: Народна књига. 1988.

Павловић, Живојин. Лов на тигрове. Београд: Просвета, БИГЗ. 1988.

Павловић, Живојин. Дивљи ветар (1-10). Нови Сад: ДП „Знање”. Београд: КВИТ Подијум. 1993.

Павловић, Живојин. Азбука. Нови Сад: Прометеј (Библиотека Моје детињство). 1997.

\section{ЛИТЕРАТУРА}

Антонић 2001: И. Антонић, Временска реченица, Нови Сад, Сремски Карловци: Издавачка књижарница Зорана Стојановића.

Арсенијевић 2007: B. Arsenijević, Slavic verb prefixes are resultative, Cahiers Chronos 17, Leiden, 197-2013.

Биверз 2009: J. Beavers et al., The Typology of Motion Expressions Revisited, Journal of Linguistics 46/2, Cambridge, 331-377.

Бopep 2014: H. Borer, Taking Form: Structuring Sense, Volume III, Oxford: Oxford University Press.

Бринтон 1988: L. J. Brinton, The Developement of English Aspectual Systems, Cambridge: Cambridge University Press.

Бурзио 1986: L. Burzio, Italian syntax: A government-binding approach, Dordrecht: Reidel.

Герке 2008: B.Gehrke, $P$ s in Motion: On the semantics and syntax of $P$ elements and motion events, Utrecht: LOT Dissertation Series 184. 
Голдберг 1995: A. Goldberg, Constructions: A Construction Grammar Approach to argument structure, Chicago: Chicago University Press.

Зварц 2005: J. Zwarts, Prepositional Aspect and the Algebra of Paths, Linguistics and Philosophy Vol. 28, No. 6, Netherlands, 739-779.

Зварц 2006: J. Zwarts, Case marking Directionality, Variation and Stability in Grammar, CASTL/CLS Workshop, Nijmegen.

Ивић 1957: М. Ивић, Једно поглавље из граматике нашег савременог језика - систем месних падежа, Годишњак Филозофскиг факултета у Новом Саду III, Нови Сад, 139-149.

Кликовац 2000: Д. Кликовац, Семантика предлога: студија из когнитивне лингвистике, Београд: Филолошки факултет.

Ковачевић 1986: М. Ковачевић, Префиксација и њен утицај на форму и семантику синтагме, Научни састанак слависта у Вукове дане 16, Београд, 119-129.

Ковачевић 1992: М. Ковачевић, Кроз синтагме и реченице, Сарајево: Завод за уџбенике и наставна средства.

Крофт 2010: W. Croft et al., Revising Talmy's typological classification of complex events, in: Hans Boas (ed.) Contrastive construction grammar, Amsterdam: John Benjamins, 201-235.

Левин 1993: B. Levin, English Verb Classes and Alterantions: A Preliminary Investigation, Chicago, London: University of Chicago Press.

Левини и Рапапорт-Ховав 1995: B. Levin and M. Rappaport-Hovav, Unaccusativity: At the syntax-lexical semantics interface, Cambridge Mass: MIT Press.

Миливојевић 2007: Н. Миливојевић, Теличне партикуле у енглеском и перфективни префикси у српском језику - глаголски вид или тип глаголске ситуације?, Годишњак Филозофског факултета у Новом Саду XXXII, Нови Сад, 397-407.

Миливојевић 2010a: Н. Миливојевић, Синтаксички субјекат као телеолошки агенс уз глаголе стварања звука у енглеском и српском језику. Годишњак Филозофског факултета у Новом Саду XXXV/2, Нови Сад, 303-312.

Миливојевић 2010б: Н. Миливојевић, Motion expression and framing in English and Serbian, у: Суботић, Љ. и И. Живанчевић-Секеруш (ур.), Сусрет култура, Пети међународни интердисииплинарни симпозијум (зборник радова), књига I, Универзитет у Новом Саду, Филозофски факултет, Нови Сад, 633-640. 
Миливојевић Наташа. 2016а: Конструкциони идиоми у енглеском и српском језику. Е-дисертаиија.http://digitalna.ff.uns.ac.rs/digitalnabiblioteka/e-disertacija; http://www.vbs.rs/scripts/cobiss?ukaz=DIS $\mathrm{P} \& \mathrm{id}=1937226925180000 \& \mathrm{rec}=3 \& \mathrm{sid}=1$ 21.05.2016.

Миливојевић 2016b: N. Milivojević, Revisiting verbs of emission: An update on some relevant theoretical accounts of lexical specification and argument structure of emission verbs, LOGOS ET LITTERA: Journal of Interdisciplinary Approaches to Text III/1, Montenegro, 25-45. http://www.ll.ac.me/treci\%20broj/LL3(1).pdf 8.07.2016.

Новаков 2005: П. Новаков, Глаголски вид и тип глаголске ситуаиије у енглеском и српском језику, Нови Сад: Футура публикације.

Перлмутер 1978: D. M Perlmutter, Impersonal passives and the unaccusativity hypothesis, Proceedings of the Fourth Annual Meeting of the Berkeley Linguistic Society, Berkeley: University of California, 157-189.

Пипер 1977-1978: П. Пипер, Обележавање просторних односа предлошкопадежним конструкцијама у савременом руском и савременом српскохрватском језику, Прилози проучавању језика 13-14, Београд, 1-48.

Пипер 2001: П. Пипер, Језик и просто, Београд: Библиотека XX век.

Пипер 2005: П. Пипер и др., Синтакса савременога српског језика, Проста реченииа (у редакиији Милке Ивић), Београд: Институт за српски језик САНУ, Београдска књига, Матица српска.

Прћић 1997: Т. Прћић, Семантика и прагматика речи, Нови Сад, Сремски Карловци: Издавачка књижарница Зорана Стојановића.

Расулић 2004: К. Расулић, Језик и просторно искуство: Концептуализаиија вертикалне димензије у енглеском и српскохрватском језику, Београд: Филолошки факултет.

Талми 1985: L. Talmy, Lexicalization patterns: Semantic structure in lexical forms, in: Shopen, T. (ed.). Language Typology and Syntactic Description Vol. 3: Grammatical Categories and the Lexicon, New York: Cambridge University Press, 57-149.

Талми 2000a: L. Talmy, Towards a Cognitive Semantics, Volume I: Concept Structuring Systems, Cambridge, MA: The MIT Press.

Талми 2000b: L. Talmy, Towards a Cognitive Semantics, Volume II: Typology and Process in Concept Structuring, Cambridge, MA: The MIT Press.

Фоли и Харли 2008: R. Folli and H. Harley, Teleology and Animacy in Extrenal Arguments, Lingua Vol. 118, Issue 2, New York, 190-202. 
Џекендоф 1990: R. Jackendoff, Semantic Structures. Cambridge, Mass., London, England: MIT Press.

Џекендоф 1997: R. Jackendoff, The Architecture of the Language Faculty, Cambridge, Mass., London, England: MIT Press.

\title{
STRUCTURE AND CLASSIFICATION OF DIRECTED MOTION CONSTRUCTIONS WITH SOUND EMISSION VERBS IN SERBIAN
}

\begin{abstract}
Summary
The present research sets out to investigate, describe and classify directed motion constructions with sound emission verbs surfacing as verbal phrase heads in Serbian. Verbs of sound emission belong to a larger subset of Verbs of emission (Levin 1993), and are semantically characterized as verbs which do not lexicalize motion: rather, they lexicalize sound emission and sound production. Within directed motion constructions, these verbes may surface as construction heads, taking an obligatory satelite phrase as an argument to the main verb. The constructions are classified according to both syntactic and semantic criteria: two syntactic types and four semantic variations are established in Serbian. The dominant theoretical frame of the research is Construction Grammar (Goldberg 1995), with the relevant insights into the typological classification of natural languages originally proposed by L. Talmy (2000a, 2000b). The study relies on a qualitative corpus analysis, and the sample comprises literary texts in Serbian and online corpus examples. The results of the analysis have indicated that Serbian dominantly behaves as a satelite-framed language with a rich morpho-syntatctic potential for encoding directed motion. The satelite class in Serbian, or the class $S$ includes verbal prefixes, prepositions and case inflections.

Key words: Construction Grammar, Serbian, verbs of sound emission, directed motion, trajectory, class $\mathrm{S}$.
\end{abstract}

